\title{
RANBP2 Gene
}

National Cancer Institute

\section{Source}

National Cancer Institute. RANBP2 Gene. NCI Thesaurus. Code C114452.

This gene is involved in both SUMOylation and nuclear transport. 